\title{
Orality in its Written Traces: Bilingual reportationes of Sermons in France (Thirteenth Century) ${ }^{1}$
}

\section{Nicole Bériou*}

The intense practice of preaching became a prominent feature of religious life in the Western Church during the thirteenth century and afterwards. The new orders of mendicant friars considered preaching as their main duty, and equipped the libraries of their convents with many tools for putting together sermons. At the same time, attending sermons and taking down notes which could be reused for delivering new sermons became a habit with theology students in Paris. Manuscripts written by these students for private use document this process in various states of composition. Bilingualism, either with the juxtaposition of French and Latin words or in the use of a Latinised French which could be easily transposed into the vernacular, does not reflect the oral performance. But these reportationes, which are a selection of what the preacher said, suggest that their authors paid particular attention to the challenge of integrating elements of biblical commentary into the culture of the laity: interpretations of biblical narratives, verses and proper nouns are prevalent and, reversing the process, we find an exploration of the rich resources of words which belong to common culture but also have a resonance in the field of religious experience.

Keywords: preaching; oral communication; reportationes; bilingualism; French; Bible; metaphors

Among professionals of the spoken word - those who regularly practised different kinds of oral communication in medieval society -, preachers occupy a prominent position, alongside teachers, jugglers, storytellers, town criers and other messengers. ${ }^{2}$ From the thirteenth century onwards, the preacher became a familiar figure, especially (but not only) in towns, due to the important new role played by the mendicant friars.

Not all friars were litterati in the sense of being Latin scholars. But those whose ideas are, up to a point, still accessible to us through manuscripts all belong to the same cultural elite: they used written Latin on a daily basis. During their theological studies at university, the friars discussed and analysed the meaning of the Bible, which was the primary source of their preaching.

* Correspondence details: Nicole Bériou, 20 rue Croix des Petits-Champs ,75001 Paris, France; email: nicole. beriou@gmail.com.

1 I have already published various contributions on this theme. See Bériou, Prédication au béguinage; Prédication de Ranulphe; Reportation des sermons parisiens; Latin and the vernacular; Avènement des maitres; Sermons latins après 1200; Latin et langue vernaculaire; Comment parler au peuple. This article is an attempt to bring together previous considerations and examples and to evaluate the resources and limits of this documentation with regard to gaining an understanding of the methods and effects of religious communication at a time when preaching became a common practice, at least in towns.

2 Delcorno, Professionisti della Parola; Bouhaïk-Gironès and Polo de Beaulieu, Prédication et performance. 
Many other kinds of Latin sources could be found in their libraries: distinctions, saints' lives, exempla collections, and model sermons, all of which they dipped into liberally when composing their own sermons. ${ }^{3}$ Thus, the majority of documents which throw light on their activity as preachers come to us through the filter of Latin. Obviously, this mode of transmission impedes our immediate understanding of the real conditions of medieval preaching, since the scholarly language could not have been used for communicating with ordinary members of the laity. Oral communication can take many paths. Since the New Testament's account of the Pentecost, which shows the Apostles glorifying God in various tongues, this miracle has remained a point of reference. ${ }^{4}$ The message delivered by the preacher can be effective, even when the speaker's language is not the same as that of his audience. A famous medieval example of this is told about Saint Bernard of Clairvaux, who preached successfully in French when he went to Germany. In such a case, witnesses underline the positive effects of a dramatic speech, whose reception can provoke a range of emotions and internal conversions. ${ }^{5}$ Nevertheless, the ordinary activity of preaching in church during the liturgical services, as developed and recommended by the Church since at least the ninth century or even earlier, ${ }^{6}$ relies on the twin requirements of addressing both the intellect and the emotions.

Based on the biblical texts read during Mass, preaching was also supposed to make the sacred teaching of the Scriptures accessible to simple people who knew no Latin. This is made clear in the opening of a sermon by Évrard de Saint-Quentin, a Dominican preacher from Picardy, who spoke as follows at the church of Saint-Germain l'Auxerrois in Paris in 1273:

Good people ought to listen willingly. Just as if somebody might say to his doctor: »Tell it in [understandable] language", so [at the moment when] the Gospel [is read] they stand up and incline the head, even though what the Gospel says is in a language that you do not understand any more than you do Flemish (...). So when someone comes and speaks in your own language, it is like food: the Word gives sustenance to your soul. This is how the Lord became known according to the Gospel [on the road to Emmaus]: "They recognised the Lord in the breaking of the bread". [This bread is given] to you whole and entire; that is why, if someone comes to break it for you, you should listen to him willingly. Let us pray. ${ }^{7}$

For an enlightening study of one of these model collections in relation to the library of the convent of the Augustinian friars in York where it was compiled and used, see Akae, Mendicant Sermon Collection.

4 Vecchio, Langues de feu; id., Dispertitae linguae.

5 See Constable, Language of preaching. Later on, during the fifteenth century, the systematic mixture of Latin and the vernacular in certain written sermons may reflect actual preaching, performed as a dramatic oration. For examples of this practice in Italy, see Lazzerini, Per latinos grossos, and $i d$., "Da quell'arzillo pulpito«; in France, see Werner, Sermon sur l'Enfant prodigue; in England, see Wenzel, Macaronic Sermons.

6 Lauwers, Parole de l'Église.

7 Here are the hasty notes as they have been transmitted by the listener: "Bone gentes debent multum libenter audire. Sicut si quis diceret medico: dicatis in una lingua. Et quando in euangelio surgunt et removent capita et tamen in euangelio dicitur in lingagio quod non intelligitis plus quam in flamingo (...). Quando ergo aliquis uenit qui dicit tibi in lingua tua est sicut esca. Sic uerbum sustinet animam tuam et sic cognoscitur Dominus in euuangelio (Luc 24, 35): Cognouerunt Dominum in fractione panis. Totum integrum est quoad uos, et ideo, quando uobis uenitur ad frangendum, libenter debetis audire. Ideo rogabimus." (Paris, BnF, lat. 16481, fol. 307ra) I have proposed in square brackets some expansion of this text to improve understanding. 
It is true that in a city like Paris, where preaching was provided by men from many different countries, not all preachers could speak perfect French. However, they all made an effort to speak to the citizens in that language. Saint Bonaventure puts this very nicely in a sermon to Cistercian nuns in the church of Saint-Antoine, in Paris:

Orietur vobis timentibus nomen meum sol iustitie, in Malachi. This means in French that the sun of justice is the Lord Jesus Christ, who arises by grace in the hearts of those who are in fear of God and listen to his word with due respect and fear (...) As you can see, when the sun shines through part of a stained glass window, finely designed and made of lovely colours, the light is amazingly beautiful. But when the glass is not transparent and not so well designed, the light coming through does not seem so lovely - and yet, in itself the light is just as clear, whatever the state of the window that it passes through. In the same way, the word of God may sometimes be expressed through a mouth that is not rightly adapted to speak the language in which it preaches, as in my case when I speak French (...); but still, the word of God always has the same force, no matter what kind of mouth it passes through: So, never mind, since you can understand me. ${ }^{8}$

Michel Zink has clearly shown in his thesis that written "sermons " preserved in the romance languages do not, with rare exceptions, reflect real preaching. ${ }^{9}$ In Italy, the first written traces of reportationes that we know of date from the beginning of the fourteenth century, when the sermons of Giordano da Pisa in Florence were noted down in the vernacular by lay members of the audience; Carlo Delcorno has extensively studied these reportationes. ${ }^{10}$ Slightly earlier, another kind of report provides a rich seam that can be exploited in order to gain an idea of "oral performance «: reportationes made in Paris by university students. ${ }^{11}$ Such notes were then exploited by them as cheap collections of models. They are written in a hybrid language with Latin dominant, but with traces of the vernacular interspersed throughout. The construction of the sentences follows the French syntax closely, so that texts seem to be written in a Latinised French. In some cases, manuscripts which contain these personal notes have been dispersed, but a significant number have also been preserved among the vestiges of the medieval libraries in Paris, especially that of the medieval college of the Sorbonne in the Bibliothèque nationale. That is also where the sermons of Évrard and Bonaventure, which I quoted briefly at the beginning of this paper, are still to be found.

8 "Orietur uobis timentibus nomen meum sol iustitie, in Malachia $(4,2)$. Et ualet tantum in gallico quod sol iustitie est Dominus Iesus Christus, orietur per gratiam in cordibus eorum qui Deum timent et uerbum suum reuerenter et cum timore audiunt. (...) Et sicut uos uidetis quod sol uel lumen solis, quando intrat per unam uitream pulchram et bene dispositam et coloratam, tunc illud lumen est ita pulchrum quod mirum est; quando autem transit per fenestram uitream non ita claram nec ita bene dispositam, non est ita clarum ut apparet lumen solis, sed ita clarum est in se, transiens per unam fenestram male dispositam sicut per fenestram bene dispositam. Sic uerbum Dei quando transit per os male dispositum ad loquendum langagium in quo predicat ut ego gallice, cum uerbum Dei eamdem habeat uirtutem per quodcumque os transeat (...) sic, licet ego nesciam bene loqui gallice, non tamen propter hoc uerbum Dei quod debeo proferre in se minus valet. Ideo non curetis de hoc, dum tamen me intelligere possitis." (prothema of a sermon to the Cistercian nuns of Saint-Antoine in Paris for the feast of Saint Mark in 1273, Sermo 44 de diversis, ed. Bougerol, 580).

9 Zink, Prédication en langue romane.

10 Delcorno, Giordano da Pisa; and his recent article on Comunicare dal pulpito.

11 See Dal pulpito alla navata, and also Bériou, Avènement des maîtres. 
Containing, as they do, only traces of the vernacular, these notes or reportationes inevitably distort the oral performance of the original language used by the preacher, which was French. Nevertheless, they bring us closer to the real performance than all the books which preachers used as preparatory tools; these can only throw light indirectly on the practice of preaching. Therefore, while remaining conscious of the limitations of such witnesses, it is important to consider them when we attempt to understand what actually happened when preachers spoke to the laity, and this at a time when regular preaching was becoming common.

From the strict point of view of oral expression, the texts would obviously be more faithful to the original if they were written in the language in which sermons were preached. That is what makes Giordano's sermons in Florence of inestimable value. ${ }^{12}$ Nevertheless, the skill of Parisian students, who were accustomed to taking notes during lectures, guarantees a high level of confidence in their ability to capture and retain the structure of the speech and the main ideas, which they expressed in their own words.

A key moment in the transition to a common practice of their reportationes of sermons, at least in Paris, could be the foundation, in 1257, of the college later called the Sorbonne from the name of the founder, Robert de Sorbon, a canon of Notre-Dame. Initially intended as a students' residence, providing board and lodging for theology students, the college's vocation, according to its founder, was to provide the Church with good preachers. Taking notes during lectures (which were given in Latin) and during sermons (delivered either in Latin or in the vernacular) was part of their training. Many graduates, later fellows of the Sorbonne, donated their personal books and manuscripts to the library of the college. This ensured the survival of a large number of documents containing impromptu notes, made rapidly during sermons, without any particular effort of style, but still with all the attention to the spoken word required when learning how to compose and deliver a good sermon..$^{13}$

What we now call reportationes, or reports of sermons, are mostly texts written by students in a developed version. Two stages of composition usually occurred. First, concise notes were taken down while listening to a preacher, and then they were completed at home from memory. Some of these clerical listeners may have been in the habit of condensing the subject matter immediately in their own words, that is, of making rapid summaries, on the spot, of what the preacher was saying. But there is reason to believe that the work of reconstituting the developed text was most often done at a later stage - in which case, during the first stage - that is, when they listened to a vernacular sermon - students concentrated their attention on making a simultaneous translation, into Latin, of what they heard the preacher saying in the vernacular. As far as possible, they attempted to retain the key words and certain phrases, which would enable them to reconstitute later, in peace and quiet, the logical argument and the persuasive rhetoric of the sermon as they heard it. That, at any rate, is what emerges from documents, preserved by chance and produced during the 1270 , by Raoul de Châteauroux, one of the first fellows of the Sorbonne. The two above-mentioned

12 See Delcorno, Lingua dei predicatori.

13 For a detailed study of reportationes made by fellows of the College of Sorbonne during the thirteenth century, see also Bériou, Avènement des maîtres. 
sermons delivered by Évrard de Saint-Quentin and Bonaventure were recorded by him, the first partly in rough notes, the second in a more readable way. Two of his manuscripts illustrate these two stages of composition. In some cases we have only his brief notes, often made in a manner so compact as to be barely comprehensible. At other times, the sermons are given in a later version, more or less written out in full. It can also happen that for the same sermon both versions have survived, the notes as well as their development, and this makes it possible to observe more precisely how the reporter worked.

Here is an example of these two states of the reportatio of a sermon delivered by the Franciscan Jacques de Provins in the church of Saint Paul (in the two extracts, I have drawn attention to words in the vernacular, which are in quotation marks). The first, on the left, is the rough draft registered in the collection of sermons which was collected by Raoul de Châteauroux in 1273 (Paris, BnF, lat. 16481, fols. 310r-311r). The second, on the right, is the written-out text, copied in another manuscript where pieces of the same sermons are preserved under headings, according to the topics with which they deal (Paris, BnF, lat. 16482, fols. $65 \mathrm{r}-65 \mathrm{v}$, under the word »Karitas«): 
Sermo fratris Iacobi de Pruuinis minorum ad Sanctum Paulum statim post ${ }^{14}$

In caritate radicati et fundati ut possitis comprehendere cum omnibus sanctis que sit longitudo latitudo sublimitas et profundum ${ }^{15}$

$<$ Prothema $>$ Sicut sol indifferenter lucet, sic uirgo regi[n]a etc., bernardus in laudem / (310v) uirginis, et ualet tantum: sicut communiter omnibus sine differentia et "chalendi«, sic uirgo regi[n]a parata uirtutibus, loco de »oustrage, ne ginde ne fresiaus, ne coife ne capias«. Et dicit quod magno corde iuuat quemlibet, nec deficit plus quam sol, ideo quod ita breuiter intelligatis et proficiatis, aue maria.

$<$ Thema $>$ In caritate radicati etc.

in epistola modo lecta apostoli, et ualet tantum: scitis »enraciné bien et fundez« in caritate. »comprendre et apprendre« quid longum patientie. quem »longuement«.

latum sue caritatis et curialitatis qui diligit integraliter omnes.

respicere quid altum et profundum. dignitatis et carceris in qua captiuos.

Ideo dicit in caritate radicati.

et bene quia ipsa est radix omnis boni.

sicut domus uel arbor cadit, sic etc.

debetis scire quod ipsa est graciosa, uirtuosa, nobis autem preciosa.

\section{KARITAS}

(

In caritate radicati et fundati ut possitis comprehendere cum omnibus sanctis que sit longitudo latitudo sublimitas et profundum. In epistola hodierna modo lecta, et ualet tantum in gallico: scitis bene radicati, »enracinez et fundez « in caritate ut possitis comprehendere et apprehendere quid sit longum paciencie, "quen longuement" Christus passus est et uos debetis pati; quid sit latum diuine caritatis et curialiatis, qui diligit nos omnes integraliter, "qui nos ama touz entrinement «; quid sit altum siue sublime dignitatis diuine, et quid profundum carceris, in quo ponet miseros peccatores; et bene dicit in caritate radicati, ne aliquis possit uos ab ista caritate separari, quia ipsa est radix, »la rachine", omnis boni. Et sicut uidetis quod domus uel arbor que non est bene radicata cito corruit, sic homo et femina qui non est bene radicatus in caritate cito in peccato ruit. Et debetis scire,

14 According to the liturgical calendar of the year, which guides the classification of the sermons in this manuscript, this means that the sermon was delivered on the sixteenth Sunday after Pentecost, as was the preceding sermon in the collection.

15 Eph 3, 16. 
Non est porcus sancti antonii qui currit "aval cele vile ${ }^{16}$ sed uirtus quedam que docet deum teneri carum super omnia. propter deum et proximum.

Graciosa deo, in se uirtuosa, et nobis utilis. ecce magnus sermo, sed dicam quod potero.

Graciosa deo. bene ostendit quia docet "an toz« in obedientia eius, que domina est alterum uirtutum. maior autem hec est.

Bernardus: „Soli caritati licet« etc. hoc dixit in laudem domine caritatis, unde melius quam per digitum tenuistis creaturam (sic). quia descendere

[blank: about five letters]

amare nos tripliciter fecit, ut nos amaret "lauiament«, tenere et integre. Primo dico quod tenuit eum ita curtum quod precepit ei quod nos amaret "lauiament «, plus quam socius socium. mater. uel domina baronem.

et hoc totum fecit abbatissa uirtutum (...) belle gentes, quod caritas fuit Deo multum graciosa, in se uirtuosa, utilis et fructuosa. Et debetis scire quod non est porcus sancti Antonii qui currit "a val cele vile«, sed uirtus quedam que docet Deum teneri carum super omnia, et proximum propter Deum. Quod autem caritas fuerit tantum Deo graciosa, in se uirtuosa etc, de quolibet esset unus magnus sermo, sed dicam quod potero.

Quod fuit Deo multum graciosa, bene ostendit quia Deus se posuit »de tut en tut « in obedientia domine caritatis, que est domina aliarum uirtutum et maior omnibus aliis, jnde $\mathrm{Ps}^{17}$; Bernardus: "Soli caritati licet« etc; hoc dixit in laude domine caritatis, unde dicit: "Domina caritas, uos melius tenuistis creatorem quam per digitum, quia uos fecistis eum de celo descendere in uterum urginalem, de utero uirginali sallire in crucem, de cruce in sepulcrum, de sepulcro in infernum, de inferno iterum in celum. ${ }^{18}$ Caritas fecit quod ipse nos amaret tripliciter, scilicet »leaument, tendrement, entirement«. Primo dico quod domina caritas tenuit eum ita curtum quod ei precepit ut nos amaret »leaument«, plus quam socius aliquis suum socium, plus quam aliqua mater suum filium, plus quam aliqua domina suum uirum, "plus que nus compeinz son compeinon, plus que nule mere son enfant, plus que nule dame son baron«, et hoc totum fecit domina abbatissa uirtutum caritas, que sic ei precepit (...)

16 While collecting alms for the order of the Antonines, that is of St Antoine de Viennois (Hospitallers), the friars brought with them a pig (which is their emblem), named "Charity", as Robert de Sorbon himself established in a sermon: "Multi sunt qui nesciunt quid sit caritas, sed credunt, quando audiunt loqui de ea, quod sit porcellus sancti Antonii, qui appellatur scharitatz « (Paris, BnF, lat. 15971, fol. 72r); in notes from another reportator of the same sermon: "Porcus sancti Antonii uocatur caritas et uenit quando sic uocatur et tamen nescit quid est caritas" (BAV, Vat. lat. 1211, fol. 52r).

17 sic pro I Cor 13,13 .

18 This itinerary of Christ is often described in sermons on his ascension: for example, Honorius Augustodunensis, Speculum ecclesiae, ed. Migne, col. 955-960. I could not find a precise reference in the works of St Bernard. 
Over 90 percent of Raoul's notes are in Latin. This is not an argument in favour of sermons delivered in Latin; such a preponderance results from the familiarity of students with Latin when they take down notes and from the advantage of doing it quickly by relying on the rich and stable system of abbreviations which they can use. In the long version, which is much easier to follow, but where the prothema is omitted, the syntax is noticeably influenced by French. As for the vocabulary, certain French words are given Latin inflections, others are left in the vernacular. At times, two words with the same meaning, one in Latin, one in French, stand side by side (here: radix/»la rachine«). In some cases, French words which were present in the rough notes have been removed in the final text, but others have been added. The reason for these changes is not clear, but additions often allow the reportator to restore rhymed formulas by expanding them from one French word in his notes. Sometimes the two languages are encountered in a single grammatical structure. Most often, a solitary French word will stand alone in the middle of a sentence, but occasionally there are short phrases, or rhyming lists, and even whole sentences, such as proverbs, for example. ${ }^{19}$ It is typical of the writer to retain, in his initial notes, words referring to concrete realities (here, for example: radix/»rachine« in French, and descendere in the citation attributed to Bernard). These then become the basis of longer developments in the text later reconstituted from memory.

Methods of reporting certainly varied a good deal. The texts written by the reportatores can be very disparate from the point of view of how accurately they recall the spoken word..$^{20}$ These students retained from the preacher what they considered important, and what they managed to note down hastily at the moment of oral delivery. The degree of attention also varies, perhaps because the listener was tired or distracted, or depending on the level of his personal interest in the subject. It can happen that the sermon, as heard, is reduced to a skeletal structure in which only a few citations from the Scripture have been preserved in support of each stage of development. ${ }^{21}$ More often, however, the content of the sermon is reproduced in its entirety, though not literally, since the rewriting is based on the notes, and the style is also affected by having passed, perhaps more than once, from one language to another.

This can be verified when we are fortunate enough to have both the preparatory work of the preacher himself and the recording of his speech, occasionally made by several listeners at the same time. Louis-Jacques Bataillon demonstrated this by comparing the autograph text of Matthew of Aquasparta with various reportationes of it made in Paris. As he says, "Nothing essential is missing, and we can even discover things which the preacher himself did not feel it necessary to write out in full, such as the prothema, patristic citations, details of an exemplum, repetition of divisions, or the beginning of a collation « - that is, an afternoon sermon which prolongs the teaching given in the morning sermon. ${ }^{22}$ In other words, it

19 In his analysis of bilingualism in sermons where English is intermingled with Latin, Siegfried Wenzel (Macaronic Sermons, 14-22) has distinguished three typical elements which are also visible in these Parisian reportationes: (a) explanation of Latin words; (b) rhymed divisions; (c) switching from one language to the other in the middle of a sentence.

20 Various examples can be found in the contributions to the conference Dal pulpito alla navata: see the contributions of Louis-Jacques Bataillon, Nicole Bériou, Jacques-Guy Bougerol and Carlo Delcorno.

21 For this schematic transmission, see, for example, Sancti Bonaventurae Sermones dominicales, ed. Bougerol; $i d$., Trois états d'un sermon.

22 Bataillon, Sermons rédigés, 77-78. 
can happen that the listener's notes are more explicit than the preacher's aide-mémoire from which he could easily improvise. ${ }^{23}$ But the opposite can also be true: sometimes a passage which is hard to understand in the notes, being too concise, becomes clear when we have access to the preacher's text. ${ }^{24}$

This hybrid language, used both by student reportatores and by the preachers themselves when preparing their sermons, tells us something of the performance: not verbatim, but as a sketch of the presence of two languages in the oral delivery. Let us now go further in trying to understand how bilingualism could work in a concrete way.

First of all, it was necessary to transpose into the vernacular at least parts of the Bible texts to be used in the sermon. This is most often the case with readings from the Gospels and the Epistles. The preacher took a verse as the theme of his sermon, using it as a basis for divisions and distinctions, which typically give structure to this new type of sermon, the sermo modernus, which became current during the thirteenth century. If we looked exclusively at collections of model sermons which were composed during the thirteenth century, dominated as they are by this new form, there would appear to be an important falling-off in the practice of making a paraphrase, in translation, of the whole Gospel reading for the day, in the manner of the Church Fathers - especially Gregory the Great in his Homilies on the Gospels. The bishop Maurice de Sully was still preaching regularly in this old tradition in the late twelfth century, judging by his model sermons proposed to the clergy of his diocese, which are based on the Gospels for Sundays and major feasts. But collections of model sermons composed during the thirteenth century are here misleading, since the reportationes made in Paris present us with a different picture, which bears precious witness to how things were actually done. While it is not systematic, a number of preachers clearly remained faithful to the older practice of retelling the whole of the Gospel passage - glossing it if necessary, though not saying so; at times they were happy enough to put the theme into context by placing the chosen verse in a condensed version of the Gospel reading.

For example, Évrard de Saint-Quentin, after the prothema of his sermon at Saint-Germain-l'Auxerrois (Paris, BnF, lat. 16481, fol. 306vb), which I have already quoted, concentrated his teaching on one verse of the Gospel of the day, which tells of the resurrection of the son of a widow of Naim (Lc 7, 11-17): Adolescens, tibi dico: surge. But first, he told the whole story, which the reportator retained only in bits and pieces, and then he paid attention to the important word for his message of conversion: "Surge", that is, you have to remove yourself far from sin:

23 As with the reportationes of Pierre de Limoges, a fellow of the Sorbonne. They can be compared to the personal notes of Robert de Sorbon, which prepare for or keep a record of his own sermons.

24 See, for example, the sermon delivered by Robert de Sorbon about the status of »béguin", which has been preserved by himself and by one of his listeners, Godefroid de Fontaines: Bériou, Robert de Sorbon. 
Adolescens tibi dico: Surge (Lc 7, 14). Legimus hodie in euangelio unum miraculum quod Dominus fecit quando ibat per terram/ sicut ille qui ubique currebat propter predicandum/ efferebatur extra portam/ sequebatur / ille qui curialis/ quod in magno dolore et lacrimis/ Sistite/ Adolescens, "jovencias«, dico quod surgas/ Et salliuit sursum statim, et »une grant freor« vel timor cepit omnem. Hoc est sensus uerbi. Solet dici communiter: "Qui bene est non se moueat«. Sed debetis scire quod nullus est ita bene sicut qui est in bono statu. Apostolus (I Cor 10,12): Qui se existimat stare videat ne cadat, id est non se moueat, ergo e contrarium, qui male est se moueat, cui potest dici: "Qui se remue desli aue«. Si homines moderni ita bene scirent quid sit peccatum et quam modicum habemus de tempore sicut sancti patres nostri, nullatenus ita de facili consentirent in peccatum. Talis habet pulcros oculos qui non uidebit diem crastinam. Ideo debemus surgere statim a peccato si simus et hoc dicit uerbum propositum: Adolescens etc. (...).

The verse of the thema is always cited in Latin first, then immediately explained in the vernacular (as Évrard does) or at least translated, as indicated by the ritual formula following the citation in the notes: et ualet tantum (or: quod uult dicere) in gallico ("which means in French «). ${ }^{25}$ Then, throughout the sermon, the thematic verse is explained: it is repeated several times, either in whole or in part, thus, no doubt, helping the listeners to memorise it, though we cannot be sure in which language. At any rate, it enjoys a particular status, standing out from the other citations used by the preacher in the course of his arguments, citations whose principal purpose is to confirm his statements. For this reason they are generally given in Latin only, unless they are used to relaunch the main argument, in which case the new citation may give rise to a discussion of its content. This habit of quoting the Bible in Latin recalls the sacred nature of Scripture, but the quotation passed by so quickly as to be probably very difficult for the audience to memorise. It thus plays a part in the discourse which might be compared with the legal practice of attaching seals to the bottom of charters: their function is mainly to guarantee the authenticity of the act.

According to the common practice of exegesis, the preachers often highlight the meaning of proper names in the Bible. Each of them can be interpreted, following a tradition handed down from St Jerome, among others. In fact, most pocket Bibles included lists of biblical names with their interpretation. Preachers made frequent use of them, but the reportatores did not always take note of the vernacular expressions which would tell us, for sure, that the interpretation had been given in French. It is quite possible that certain brief explanations, constantly found in the texts, such as Ierusalem, visio Dei; Israel, videns Deum; Iuda, confessio; Iohannes, qui est in gratia, and so on, were simply left standing in Latin, and that their currency in sermons helped listeners to memorise them in the scholarly language. In this way, preaching may have contributed to what Benoît Grévin has called the "resistible rise of the vernaculars « ${ }^{26}$ In a sermon at any rate, it was not necessarily considered a priority to make everything understandable right away by telling it in the vernacular. As a sacred language, Latin had to be given a special place, at the very least used for the citation of Scripture, whether the Latin was followed by a translation or not. In addition, preachers knew that the

25 See the sermons of Jacques de Provins and Bonaventure quoted supra, p. 197 and 194.

26 Grévin, Historien face au problème. 
level of understanding of Latin would not be the same among all members of the audience. Again, a preacher might exploit the switch from one language to the other in order to pass on a message in Latin which was aimed at the clergy. For example, if he spoke to a mixed audience, it might be prudent to use Latin where an attack against clerical abuses had a good chance of creating a scandal among the laity. ${ }^{27}$ Moreover, it sometimes appears that the part of the introduction where the structure of the sermon is announced could be given in Latin. According to Robert of Basevorn, it signified the professional and exclusive nature of preaching ${ }^{28}$ - as if the speaker wished to subvert any possible competition from uneducated lay people: he alone was capable of mastering the ars praedicandi based on the study and interpretation of Scripture.

Another process of communication moves in the other direction, from the vernacular to biblical Latin. Given the task of communicating a religious message, preachers relied, in fact, on the ordinary, everyday language of the listeners, whose vocabulary was a rich resource to be exploited. Preachers were quick to make use of proverbs, a form of folk wisdom whose succinct phrases may be compared with the citation of certain verses from Scripture. ${ }^{29}$ They took inspiration from the book of nature and from all kinds of social acts, which were familiar to the public. Pride of place is regularly given to the vocabulary of customs, habits, rituals, and common objects, words for which equivalents or analogies could be found in the Bible. Such equivalents, by creating links between daily life and the biblical subject matter, become heuristic tools, rendering the message more efficient.

One of the methods of religious communication thus consists in making use of the vernacular, which was close to physical reality and to the public's daily experience, in such a way that those words gained another level of meaning. Occasional traces of this practice may be found in the reportationes.

For example, starting with the notion of cost, a preacher can make a connection between food or anything in the marketplace which is dear to buy, and divine love, which is dear to the soul. Far from being an oversimplification, reducing our relationship to God to a banal kind of economic exchange, this idea can invite the audience to explore the gaps, to discover how different meanings of a word can lead us to a deeper understanding and a better grasp of complex realities. A sermon about charity, delivered by Robert de Sorbon, is especially telling. Robert, quoting the bishop of Paris Guillaume d'Auvergne, starts with considerations about the derivation of the Latin substantive "cari-tas" from the adjective "carus" (genitive "cari«). Then he points out that the same kind of link exists in French (from »cher" to

27 Ranulphe de La Houblonnière, Sermo 4 (at the beguinage of Paris), in festo purificationis, ed. Bériou, 2, 52-53: »Per duos turtures significatur nobis duplex castitas et mundicia cordis et corporis, uel, prout dixit frater Bonaventura, mundicia carnis et alieni cruoris, contra luxuriam et auariciam uel rapinam. Certe non esset pulchrum istam oblationem de Domino Ihesu Christo faciendam tradere uni homini ribaldo qui ueniret de immundiciis et ribaldariis sui faciendis, nec uno homicide qui numquam cessasset homines occidere in tota uita sua. Caueant ergo ne hodie istam oblationem faciant, donec se purgauerint, et precipue caueant sibi sacerdotes qui hanc eamdem olationem faciunt in sacramento altaris pro se et pro populo. Hoc dicas eis latinis uerbis, non laicalibus, propter scandalum."

28 Robert de Basevorn, Forma predicandi, ed. Charland, 244-245: "[Moderni] dicunt tamen quod (...) multi illitterati usurparent sibi actum predicationis, nisi quia uident tantam subtilitatem ad quam attingere nequeunt. Et propter eamdem causam, quando laicis predicant, premittunt thema cum diuisone sua in latino, quia hoc facere est difficile idiotis."

29 See, for example, Évrard de Saint-Quentin, quoted supra, p. 200-202. 
"cherté«); and then, looking at the notion of cost, he brings together the process of acquiring a horse, which costs a lot because the owner is fond of the animal, and the process of gaining divine love. But, of course, this does not mean that the flow of divine grace depends on the rules of the marketplace..$^{30}$ Moreover, »cherté is not always a bad thing, as Giordano da Pisa says in one of his sermons for Lent where he talks about charity in his turn, in a way which is closely related to what Robert de Sorbon said forty years earlier. ${ }^{31}$

The two-way movement between human language and the message of salvation revealed by the Scriptures can give rise to remarkable poetic images, especially in relation to Christ. In a sermon for Good Friday, the Passion is named "hachée« (hacheia) which is a humiliating, though not irreversible, slashing ritual. If somebody is guilty of a crime, this penalty can be imposed on him as a spectacular and slashing punishment. According to the Jeu d'Adam (v. 555-556 and 561-562), it is the punishment imposed after the original sin on Adam, Eve and all their descendants. The preacher can bear it in mind when he declares that Christ has taken the "hachée« upon himself in order to restore peace between God and mankind..$^{32}$

In another sermon, Philip the Chancellor develops the metaphor of Christ as a pilgrim. Here the glorious stigmata are likened to the cockle badges which pilgrims pinned on their capes, going so far as to describe the skin of the risen Christ as a cloak enriched with cockles (a chlamyda coquillata), which testify to his pilgrimage on earth and amaze the angels when he returns to heaven. ${ }^{33}$

30 "Sequitur de tertio scilicet quid sit caritas. Episcopus Willelmus dixit: ^Omnia scripta que locuntur de caritate respexi et interrogaui a multis et numquam potui scire per hec quid sit caritas. Ultimum iui ad Priscianum et ille docuit me quid sit caritas<. Legitur enim in maiori uolumine quod ad hoc genitiuum ıboni<, addita stas«, fit

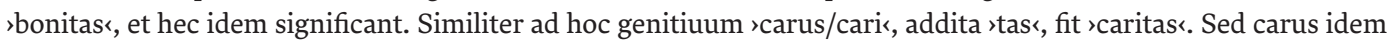
est quod ıchars`, ergo caritas idem est quod ıchartatz (...) facit Deum reputari carum. Quando aliquis diligit et habet bene carum equum suum, dicit uolenti emere: `Nolite ipsum astragare quia carus est et non darem ipsum pro minore precio quam ualeat.« Deus similiter ualde carus est.« (Robert de Sorbon, sermo in Quinquagesima, Si linguis hominum loquar, Paris, BnF, lat. 15971, fol. 72r-v)

31 "L'amore fa cara ogne cosa. Però comperi tu caro il vestimento, il cavallo, il grano, perche tu l'ami; e però si chiama carità l'amore di Dio, però ch'egli è caro, overo carestia. No è questo mal nome in tutto, anzi buono: quando il grano è caro e prezioso, c'è suo meglio; quando è vile, è per fango. Cosi Iddio: egli è caro, anzi è caristia, cioè la più preziosa cosa che sia, e è si prezioso che ogn'altra cosa à vile, e l'oro, a rispetto de la sua grandezza.« (Giordano da Pisa, Quaresimale fiorentino, ed. Delcorno, 343-344, 1. 114-123)

32 Gilles du Val-des-Écoliers, sermon at the college of St Bernard (Paris) »in gallico « (Paris, BnF, lat. 16482, fol. 67v68): Dilexit nos Deus spontanee quia nondum seruieramus ei, quod est contra multos qui habent amorem uenalem, id est "costeuse«, qua non diligunt homines nisi propter munera uel servicia, et quando deficiunt munera uel servicia deficit amor (...) Antequam enim diligeremus eum, dilexit nos (...) Sequitur (Os 14, 5): Quoniam aversus est furor meus ab eis scilicet in Passione. Tunc enim Christus ut nos Deo Patri reconciliaret "hacheiam«, "la hacieie«, sustinuit pro nobis, Rom II (= Col 1, 20): Pacificans per sanguinem crucis eius que in terris et que in celis sunt. Ista "hacheia« fuit ualde dura (...). See also Bériou, Latin et langues, 204.

33 Philip the Chancellor, sermon delivered on 1st September 1228 for obtaining alms to help the Franciscans to build their convent in Paris (see Bériou, Parler de Dieu): »(...) magnus peregrinus fuit Christus. Ut doceret nos peregrinari uoluit peregrinari. Chlamis eius, caro quam assumpsit de uellere Gedeonis et de carne beate Uirginis (...) baculus siue bordonus, huius peregrini exemplum. Pera, sacramentum passionis. Magna peregrinatio, descendisse de celo in terram (...) Chlamide scoquillata rediit post resurrectionem in carne cicatricibus ornata, et scoquillas suas ostendit beato Thome dubitanti (Ioh. 20, 27): Mitte, inquit, manum tuam etc. Et ut se probaret peregrinum, post resurrectionem euntibus in Emmaus in specie peregrina apparuit. In quo apparet quam dignus est status peregrinantium; et cum chlamide rcoquillata ascendit in celum, et mirantes angeli sic scoquillatam dixerunt, Is lxiii $(63,1)$; Quis est qui uenit de Edom etc." 
The common image of the heart as a book gives Ranulphe de La Houblonnière a chance to extend the metaphor by explaining how this book, like any good manuscript, needs to be ruled, an image which is also specified and condensed in the name "Stephanus " which means regula. ${ }^{34}$ Another preacher, who is probably Robert de Sorbon again, plays on people's typical interest in the social habits of the nobility while he is encouraging the faithful to take Holy Communion. Here he makes striking use of the image of "appetisers". These were commonly served to guests in rich households while they were waiting for the real banquet to begin. Applying this to the Christian life, Robert says that the Eucharist, while holding a very significant place in the life of the believer, is still only a foretaste of eternal bliss, the "real banquet « to which we look forward in the next life. ${ }^{35}$

The techniques of reportatio, as well as the university culture of the students and clergy, might suggest a form of Latin-dominated bilingualism. But this needs to be put in perspective when we turn to the question of oral delivery, which was mainly in the vernacular, at least in the thirteenth century. Latin, however, was not absent from these sermons during the oral performance, and the preachers' ability to make effective use of the cultural resources of two languages is highlighted by the reportatores. They pay attention to certain elements in the preacher's vocabulary. They avoid translating certain words or reformulating them in Latin, and they carefully preserve them in French in their notes, as if to underline more strongly their importance in the type of communication proper to sermons. At the same time, preachers, certainly, were not indifferent to nuances of expression in oral delivery, a resource which bilingualism allows. Even if they used it mainly when exploiting biblical material, there is no doubt that they integrated it into their speech patterns.

34 "Si uelimus cum beato Stephano in celesti palatio poni, necesse est quod nos simus in uita regulati. Est autem quadruplex regula secundum quam debemus regulari. Prima est regula consciencie (...). Secunda regula est doctrine euangelice. Hec est rectior prima regula. In libro cordis nichil debet scribi nisi fuerit regulatum regula doctrine; et sicut scriptores solliciti sunt in suis quaternis bene regulandis, sic et solliciti debemus esse in libris nostrorum cordium regulandis. De hac regula, prima ad Cor (= 2 Cor 10, 15): Spem habentes crescentis fidei uestre secudum regulam nostram, Glosa: fidei uel doctrine. Qui uero ad sermones uadit ad regulandum librum cordis sui uadit. Tertia regula est crucis dominice (..) Quarta regula est uite apostolice (...).« (Sermo in festo sancti Stephani, ed. Bériou, 280-281)

35 »Cena dominica ultima refectio est, refectio scilicet uespertina que uulgo dicitur ssouper<, ita in uespera, hoc est in fine huius uite, promittitur, et quia longa est dies presentis uite, qua terminata, cena dominica percipitur, electos suos Dominus uelut matutino cibo disieiunat ad pregustandum in spe et expectatione opulentissime cene sue, quod etiam qui curiales sunt faciunt: quando aliqua causa diutius expectari oportet conuiuium, aliquid ad pregustandum tribuunt." (Sermon Convenientibus vobis in unum, Paris, BnF, lat. 15955, fol. 132r-v. See Bériou, Eucharistie dans l'imaginaire. 


\title{
References
}

\author{
Abbreviations \\ $\mathrm{BAV}=$ Biblioteca Apostolica Vaticana \\ $\mathrm{BnF}=$ Bibliothèque nationale de France \\ $\mathrm{PL}=$ Patrologiae cursus completus. Series Latina
}

\section{Manuscripts}

BAV, Vat. lat. 1211

Paris, BnF, lat. 15955.

Paris, BnF, lat. 15971.

Paris, BnF, lat. 16481.

Paris, BnF, lat. 16482.

\section{Primary Sources}

Bonaventure, Sermo 44, de sancto Marco evangelista, ed. Jacques-Guy Bougerol, Bonaventurae Sermones de diversis 2 (Paris, 1993) 579-593.

Honorius Augustodunensis, Speculum ecclesiae, ed. Jacques-Paul Migne, PL 172.

Giordano da Pisa, Quaresimale fiorentino, ed. Carlo Delcorno (Florence, 1974).

Ranulphe de La Houblonnière, Sermo 4, in festo purificationis, ed. Nicole Bériou, La prédication de Ranulphe de La Houblonnière: Sermons aux clercs et aux simples gens à Paris au XIIIe siècle, 2 vols. (Paris, 1987) 42-57.

Ranulphe de La Houblonnière, Sermo 22 in festo sancti Stephani, ed. Nicole Bériou, La prédication de Ranulphe de La Houblonnière: Sermons aux clercs et aux simples gens à Paris au XIIIe siècle, 2 vols. (Paris, 1987) 279-284.

Robert de Basevorn, Forma predicandi, ed. Thomas-Marie Charland, Artes praedicandi: Contribution à l'histoire rhétorique du Moyen Âge (Paris, 1936).

Sancti Bonaventurae Sermones dominicales, ed. Jacques-Guy Bougerol (Grottaferrata, 1977).

\section{Secondary Sources}

Akae, Yuichi, A Mendicant Sermon Collection from Composition to Reception: The Novum Opus dominicale of John Waldeby, OESA, Sermo 7 (Turnhout, 2015).

Bataillon, Louis-Jacques, Sermons rédigés, sermons réportés (XIIIe siècle), in: Medioevo $e$ Rinascimento 3 (Florence, 1989) 69-86.

Bériou, Nicole, L'avènement des maîtres de la Parole: La prédication à Paris au XIIIe siècle, 2 vols. (Paris, 1998).

Bériou, Nicole, Comment parler au peuple dans la langue de Dieu? Les pratiques des prédicateurs dans la chrétienté latine médiévale, in: Collège de France, Institut des Hautes Études Japonaises, sous la direction de Jean-Noël Robert (ed.), Hiéroglossie: Moyen Age latin, monde arabo-persan, Tibet, Inde (Collège de France, 16-17 juin 2015) (Paris, 2019) 97-112.

Bériou, Nicole, L'eucharistie dans l'imaginaire des prédicateurs en Occident (XIIIe-XVe s.), in: Nicole Bériou, Béatrice Caseau and Dominique Rigaux (eds.), Pratiques de l'eucharistie dans les Églises d'Orient et d'Occident au Moyen Âge 2 (Paris, 2009) 879-925. 
Bériou, Nicole, Latin and the vernacular: Some remarks about sermons delivered on Good Friday during the thirteenth century, in: Volker Mertens and Hans-Jochen Schiewer (eds.), Die deutsche Predigt im Mittelalter: Internationales Symposium am Fachbereich Germanistik der Freien Universität. Berlin vom 3.-6. Oktober 1989 (Tübingen, 1992) 268-284.

Bériou, Nicole, Latin et langue vernaculaire dans les traces écrites de la parole vive des prédicateurs, in: Stéphanie Le Briz et Géraldine Veysseyre (eds.), Approches du bilinguisme latin-français au Moyen Âge: Linguistique, codicologie esthétique, Collection d'Études médiévales de Nice 11 (Turnhout, 2010) 191-206.

Bériou, Nicole, Parler de Dieu en images: Le Christ pèlerin au Moyen Âge, Comptes Rendus de l'Académie des Inscriptions et Belles-Lettres 152/1 (2008) 157-200.

Bériou, Nicole, La prédication de Ranulphe de la Houblonnière: Sermons aux clercs et aux simples gens à Paris au XIIIe siècle, 2 vols. (Paris, 1987).

Bériou, Nicole, La reportation des sermons parisiens à la fin du XIIIe siècle, Medioevo e Rinascimento 3 (1989) 87-123.

Bériou, Nicole, Robert de Sorbon, le prud'homme et le béguin, Comptes Rendus de l'Académie des Inscriptions et Belles-Lettres 138/2 (1994) 469-510.

Bériou, Nicole, Les sermons latins après 1200, in: Beverly Mayne Kienzle (ed.), The Sermon (Turnhout, 2000) 363-447.

Bougerol, Jacques-Guy, Les trois états d'un sermon de saint Bonaventure, in: Medioevo e Rinascimento 3 (Florence, 1989) 37-49.

Bouhaïk-Gironès, Marie and Marie Anne Polo de Beaulieu (eds.), Prédication et performance du XIIe au XVIe siècle (Paris, 2013).

Constable, Giles, The language of preaching in the twelfth century, Viator 25 (1994) 131-152.

Dal pulpito alla navata: La predicazione medievale nella sua recezione da parte egli ascoltatori (secc. XIII-XV), Medioevo e Rinascimento 3 (1989) 3-323.

Delcorno, Carlo, Comunicare dal pulpito, in: Isa Lori Sanfilippo and Giuliano Pinto (eds.), Comunicare nel Medioevo: La conoscenza e l'uso delle lingue nei ecoli XII-XV (Convegno at Ascoli Piceno, nov. 2013) (Rome, 2015) 185-208.

Delcorno, Carlo, Giordano da Pisa e l'antica predicazione volgare (Florence, 1975).

Delcorno, Carlo, La lingua dei predicatori: Tra latino e volgare, in: Società internazionale degli studi francescani (ed.), La predicazione dei frati dalla metà del'20o alla fine del'30o (Atti del XXII Convegno internazionale, Assisi, 1994) (Spoleto, 1995) 21-46.

Delcorno, Carlo, Professionisti della Parola: Predicatori, giullari, concionatori, in: Tra storia e simbolo: Studi dedicati a Ezio Raimondi (Florence, 1994) 1-21.

Grévin, Benoît, L'historien face au problème des contacts entre Latin et langues vulgaires au bas Moyen Âge (XIIe-XVe siècle): Espace ouvert à la recherche. L'exemple de l'application de la notion de diglossie, Mélanges de l'École française de Rome: Moyen Âge 117/2 (2005) 447-469.

Lauwers, Michel, Parole de l'Église et ordre social: La prédication aux VIIIe-IXe siècles, in: François Bougard (ed.), Le christianisme en Occident du début du VIIIe au milieu du XIe siècle (Paris, 1997) 87-107.

Lazzerini, Lucía, »Da quell'arzillo pulpito«: Sermo humilis e sermoni macaronici nel quaresimale autografo di Valeriano da Soncino, o.p., Medioevo e Rinascimento 3 (1989) 171-239.

Lazzerini, Lucía, Per latinos grossos: Studio sui sermoni mescidati, Studi di filologia italiana 29 (1971) 219-339. 
Vecchio, Silvana, Dispertitae linguae: Le récit de la Pentecôte entre exégèse et prédication, in: Peter von Moos (ed.), Zwischen Babel und Pfingsten: Sprachdifferenzen und Gesprächsverständigung in der Vormoderne (8.-16. Jh.) (Vienna, 2008), 237-251.

Vecchio, Silvana, Les langues de feu: Pentecôte et rhétorique sacrée dans les sermons des XIIe et XIIIe siècles, in: Rosa Maria Dessi and Michel Lauwers (eds.), La parole du prédicateur, Ve-XVe siècle, Collection d'Études médiévales de Nice 1 (Turnhout, 1997) 255-269.

Wenzel, Siegfried, Macaronic Sermons: Bilingualism and Preaching in Late-Medieval England (Ann Harbor, 1994).

Werner, Dorothée, Le sermon sur l'Enfant prodigue de Michel Menot (1520): Introduction, édition critique, étude lexicologique, Beihefte zur Zeitschrift für Romanische Philologie 227 (Tübingen, 1989).

Zink, Michel, La prédication en langue romane avant 1300 (second edition) (Paris, 1983). 